\title{
Oncothermia in Combination with Vitamin C Infusion for Non-small Cell Lung Cancer: a Case Report
}

\author{
Jun Wen Ou, Yi Min Lu, Xin Yu Zhu, Clifford L.K. Pang \\ Cancer Center, The Affiliated Clifford Hospital of Jinan University, Guangzhou, Guangdong 511495, China
}

\begin{abstract}
We herein report an advanced case (T3N3M0, Stage IIIB) of squamous cell lung cancer. The patient survived beyond 5 years only receiving intravenous vitamin $\mathrm{C}$ (VitC) infusion combined with modulated electrohyperthermia (mEHT, trade name: oncothermia).

Key words: Modulated electrohyperthermia; High-dose vitamin C; Advanced NSCLC; Survival time, Quality of life
\end{abstract}

\section{Introduction}

Lung cancer is one of the most common malignant tumours worldwide. Lung tumours have the highest cancer mortality of all cancers in both sexes $(28 \%$ and $26 \%$ in men and women, respectively). It is also the most common cancer type and the leading cause of cancer mortality in China [1]. The majority of cases (approx. 85\%) are non-small cell lung cancers (NSCLC) [2]. When the disease is recognised in its localised state, it has a five-year survival rate of $52 \%$, but the patients diagnosed at advanced regional or far distant metastatic stages have survival rates of only $25 \%$ and $4 \%$, respectively.

The intravenous (IV) infusion of vitamin C (VitC; L-ascorbate, ascorbic acid) has been used for many years as an alternative anticancer therapy. High-dose VitC may have a prophylactic effect against lung cancer [3], as reported in a meta-analysis of 18 articles including 21 studies involving 8,938 lung cancer cases. Estimations based on dose-response analyses showed a risk reduction in lung cancer by $7 \%$ for every $100 \mathrm{mg} /$ day increase in the intake of VitC. Moreover, refractory cases could also be re-sensitised by VitC [4].

Early reports of the usefulness of VitC in cancer therapy go back to the early 1970s [5]; where increased survival of patients with advanced cancer was observed when they were treated with high-dose IV VitC. However, those studies were observational and retrospective in nature [6,7]. Later, well-designed randomised controlled trials failed to demonstrate a significant survival benefit [8,9], although those trials used high-dose oral VitC.

The pharmacokinetics of the oral and IV applications are very different [10], and may explain the disappointing results of the later trials. For example, IV VitC can bypass the tight control of oral doses [11]. When oral doses exceed

Corresponding Author: Jun Wen Ou, PhD. Cancer Center, The Affiliated Clifford Hospital of Jinan University, No. 3 Hongfu Rd., Panyu, Guangzhou, Guangdong 511495, China. Tel: +86 1355602 1810; Fax: +86 208451 8400. Email: oujunwen66@163.com
$200 \mathrm{mg}$, it can hardly increase the plasma concentrations deal to rapid metabolism [11]. The IV intake of VitC can produce concentrations around $5 \mathrm{mM}$, which cannot be achieved orally. Such high-dose IV VitC produces high blood-plasma concentrations that could be 70- to 100fold higher than the maximally-tolerated oral doses $[8,11]$. Plasma VitC concentrations as high as $20-30 \mathrm{mM}$ were safely achieved with IV $[11,12]$. It is well recognised that intravenous VitC can produce sustained $(>4 \mathrm{~h})$ plasma concentrations greater than $10 \mathrm{mM}[9,10,14,15]$. In contrast, oral intake cannot provide plasma concentrations higher than $300 \mu \mathrm{M}$ [11]. In the last 10 years, an increasing number of studies have indicated that VitC at pharmacologic concentration can selectively kill cancer cells [16,17]. Highdose VitC in the plasma is not an antioxidant, however, it is a pro-oxidant [18], and appears to be particularly high in the interstitial fluid surrounding tumour cells, killing them or inhibiting their growth, while leaving normal cells intact $[9,16,17]$.

Laboratory studies showed that the concentrations achieved by high-dose VitC have redox properties and can decrease the proliferation of lung, prostate, pancreatic, and colon cell lines [13]. Different studies have reported several potential anticancer mechanisms associated with IV VitC, which include apoptosis [19], DNA damage and ATP depletion [20], cell cycle arrest [16], autoschizis [21], and autophagy [22]. Intravenous VitC has been generally well-tolerated in clinical trials. In fact, four human studies indicated that high-dose VitC infusions can improve the quality of life and decrease cancer-related side effects [23,24].

We recently applied modulated electrohyperthermia (mEHT, trade name Oncothermia) as complementary treatment with high-dose IV VitC. mEHT is a complementary therapy currently used for cancer patients. It has long been used in clinical practice for various malignant diseases, with efficacy proven by the numerous documented case reports and clinical studies. There have been some published case reports [25-30] and studies [31-33], showing its efficacy for the treatment of NSCLC and even in small cell lung cancer 
(SCLC) [34]. mEHT is based on the modulated electric field effect, which works in synergy with heat [35]. The key advantage of this method is the nano-range energy liberation, rather than overall heating of the target [36].

These facts motivated our team to use high-dose VitC for NSCLC together with mEHT, and no other standard therapy was included in the protocol.

\section{Materials and Methods}

A 69-year-old man was referred to us 6 years ago for coughing and haemoptysis. A chest computed tomography (CT) scan revealed a solitary pulmonary nodule in the left upper lobe, enlarged lymph nodes in the supraclavicular fossa, mediastinum and pericardial effusion, and left pleural effusion (Figure 1A). A fibre-optic bronchoscopy was performed, and the pathology report indicated moderately-differentiated squamous cell carcinoma of the left lung. A physical examination revealed a barrel chest, thoracic symmetry, and disappearance of left lung breath sounds. The Karnofsky score was 80 . The patient's height was 1.65 $\mathrm{m}$, weight was $51 \mathrm{~kg}$, and body mass index (BMI) was 18.73. The Patient-Generated Subjective Global Assessment (PG-SGA) score was 5. The result of the Nutritional Risk Screening 2002 (NRS 2002) was $>3$ points. The final diagnosis was left lung squamous cell carcinoma with multiple lymph node metastasis (T3N3M0, Stage IIIB) and chronic obstructive pneumonia. His medical history included hypertension and a history of diabetes for many years. He had also smoked two packs a day for many years, but quit smoking three years before the disease was diagnosed.

The case was considered to be inoperable, and the patient refused to undergo chemotherapy and radiotherapy. We therefore administered IV VitC in combination with modulated electro-hyperthermia (mEHT, trade name: Oncothermia) from October 2010 to April 2011.

This patient had a relatively low VitC level $(25.6 \mu \mathrm{mol} / \mathrm{L})$ before the treatment in comparison with the healthy Chinese reference level (34.1 to $58.5 \mu \mathrm{mol} / \mathrm{L})$. He received VitC at 1 $\mathrm{g} / \mathrm{kg}$ at a rate of $0.5 \mathrm{~g} / \mathrm{min}$. The treatment was administered 3 times a week for a total of 25 infusions, and was given simultaneously with mEHT. The mEHT was administered as $60 \mathrm{~min} / \mathrm{session}, 3$ times a week, for 8 weeks, for a total of 25 sessions from 2010 to 2014. The power of mEHT was gradually increased from $135 \mathrm{~W}$ to $150 \mathrm{~W}$ based on the patient's actual tolerance. The applicator used was $7.1 \mathrm{dm}^{2}$. The applied energy range in one session was between 486 $\mathrm{KJ}$ and $540 \mathrm{KJ}$.

The applied mEHT technique (EHY2000, Oncotherm $\mathrm{GmbH}$, Germany) employed rigorously impedance-matched capacitive coupling [37]. The time-fractal amplitude modulated radio frequency (RF) was chosen to use a $13.56 \mathrm{MHz}$ carrier, which is considered to be absorbed in the membrane rafts of the cancer cells [38]. This method heats heterogeneously, abandoning the classical concept of isothermal mass heating. Instead, it concentrates the absorbed energy on the intercellular electrolytes, leading to microscopic temperature differences far from thermal equilibrium. The large temperature gradient between the intra- and extracellular liquids results in activation of signalling pathways for natural programmed cell death, avoiding the toxic effects of simple necrosis [39].

\section{Results}

The tumour size was measured by chest CT scans after each treatment cycle (25 treatments). The tumour shrank by nearly $50 \%$ after the first treatment cycle. We were able to follow this patient for 5 years; the treatments greatly improved his quality of life, and he remains well with no evidence of progression in the lung mass (so far, he has survived 61 months). He experienced no adverse events attributable to oncothermia or VitC infusion.

His haemoptysis disappeared after 12 treatments. The patient gained $3 \mathrm{~kg}$ and the Karnofsky score increased to 100 points one month after the completion of 25 sessions of treatment. The PG-SGA score decreased to 2. A subsequent CT scan suggested that the left upper lobe consolidation
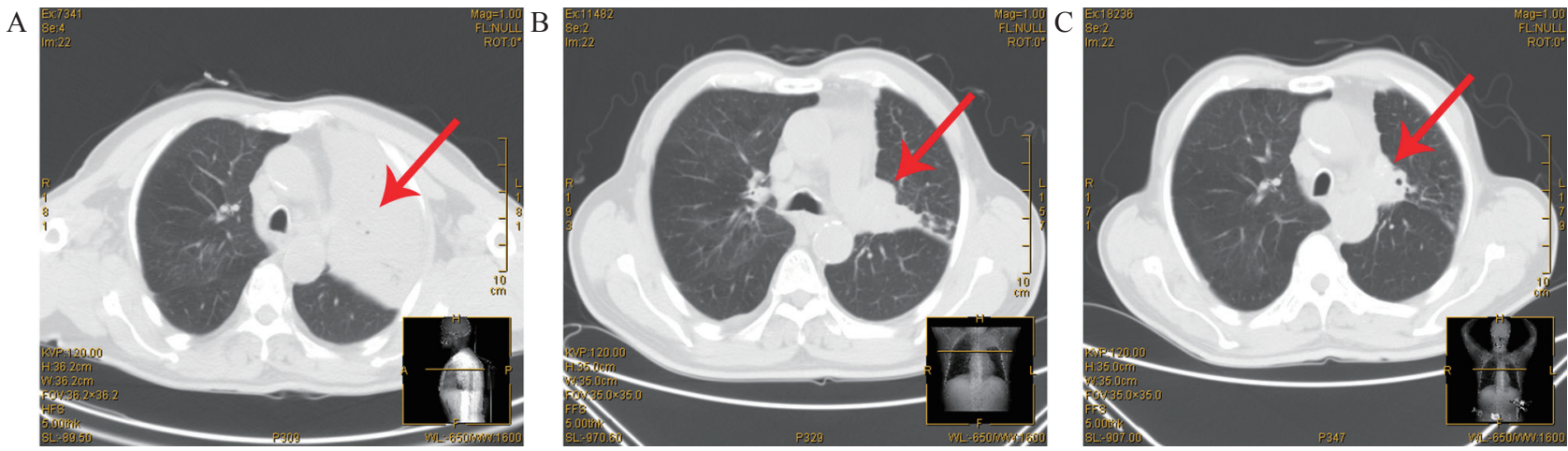

Figure 1 Three pictures indicating the changes in obstructive atelectasis from 2010 to 2012 at the same level (lung window). (A) 2010: Atelectasis of the left upper lobe at the apical segment and apico-posterior segment, pulmonary consolidation: $120.9 \mathrm{~mm} \times 87 \mathrm{~mm} \times 80 \mathrm{~mm}$. (B) 2011: Left upper lobe showed partial atelectasis, with pulmonary consolidation range narrowed in comparison with 2010 : $109.4 \mathrm{~mm} \times$ $62.2 \mathrm{~mm} \times 70 \mathrm{~mm}$. (C) 2012: Left upper lobe showing lung re-expansion 
was reduced, and the tumour had shrunk slightly in April 2011 (Figure 1B). The patient continued to receive IV VitC and oncothermia for another 30 sessions of treatment from April 2011 to April 2012. The coughing and haemoptysis had both disappeared after completion of the treatments. One month after completion of the treatments, the CT scan showed re-expansion of the previously collapsed left upper lobe, and the tumour size had further decreased in April 2012 in comparison with the 2011 scan (Figure 1B\&C). The patient felt well and did not return for any treatments in 2013. However, he complained of cough and shortness of breath and returned in March 2014.

A CT scan was performed at that time, and it was observed that there was an abrupt truncation of a bronchus from an obstruction of the left upper lobe, compensatory emphysema of the right lung, and an increase in the tumour size by $10 \mathrm{~mm}$ and the left lung tumour lesions had increased, with a small amount of pleural effusion in the left lung (Figure 2A). We administered another 40 sessions of $\mathrm{VitC}$ infusion in combination with oncothermia using the same protocol. All symptoms were relieved after 20 sessions of treatment. A subsequent CT scan suggested that the atelectasis and obstructive pneumonia were improved and that the tumour size had shrunk, with the pleural effusion disappearing in July 2014 (Figure 2B). He received VitC infusion and oncothermia for a total of 25 sessions in 2015.
The plasma VitC level of the patient had increased to 10.05 $\mathrm{mmol} / \mathrm{L}$ at the end of each infusion.

The patient has regularly received 25 to 30 sessions of $\mathrm{VitC}$ infusion with oncothermia during the past three years. He experienced no adverse events attributable to $\mathrm{MEHT}$ and VitC infusion. The VitC level was increased, and the C-reactive protein (CRP) level and some of the tumour markers were significantly decreased after every treatment cycle (Table 1), findings which were consistent with other studies [40]. The tumour size shrank by nearly $50 \%$ after the first treatment cycle. We were able to follow this patient for 5 years. The treatments greatly improved his quality of life, and he remains well at present (61 months after presentation); however, he refuses to undergo another CT scan.

\section{Discussion}

There have been no previous studies reporting the application of mEHT in combination with VitC infusion in the treatment of cancer patients. There have been previous studies that reported that the overall survival time for NSCLC patients receiving mEHT was 16.4 months [36], which is shorter than our case (61 months to date).

Although additional studies are needed, we recommend this treatment because there were not apparent effects (from the mEHT or IV VitC), and the patient experienced a good quality of life. We hypothesise that the success is a conse-
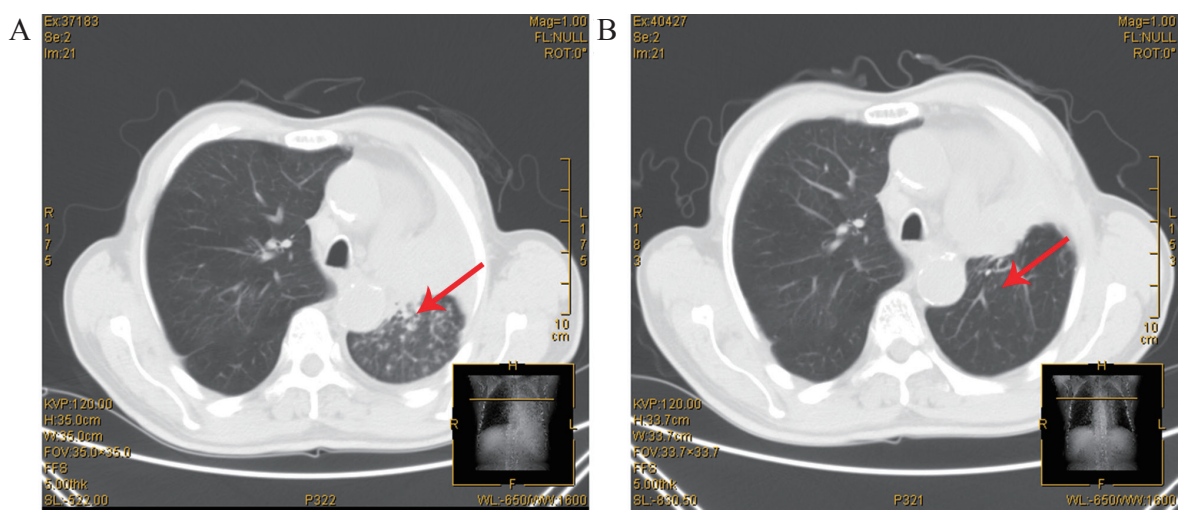

Figure 2 Improvement of the atelectasis of the left lobe and obstructive pneumonia.

(A) March 2014; (B) July 2014

Table 1 Relevant lab results from 2011 to 2014.

\begin{tabular}{ccccccccccccc}
$\begin{array}{c}\text { HGB } \\
(\mathrm{g} / \mathrm{L})\end{array}$ & $\begin{array}{c}\text { RBC } \\
\left(\times 10^{12} / \mathrm{L}\right)\end{array}$ & $\begin{array}{c}\text { WBC } \\
\left(\times 10^{9} / \mathrm{L}\right)\end{array}$ & $\begin{array}{c}\text { ALB } \\
(\mathrm{g} / \mathrm{L})\end{array}$ & $\begin{array}{c}\text { PA } \\
(\mathrm{mg} / \mathrm{L})\end{array}$ & $\begin{array}{c}\text { CRP } \\
(\mathrm{mg} / \mathrm{L})\end{array}$ & $\begin{array}{c}\text { Lymphocytes } \\
\left(\times 10^{9} / \mathrm{L}\right)\end{array}$ & $\begin{array}{c}\text { CEA } \\
(\mathrm{ng} / \mathrm{mL})\end{array}$ & $\begin{array}{c}\text { CA15-3 } \\
(\mathrm{U} / \mathrm{mL})\end{array}$ & $\begin{array}{c}\text { CA19-9 } \\
(\mathrm{U} / \mathrm{mL})\end{array}$ & $\begin{array}{c}\text { SCC } \\
(\mathrm{ng} / \mathrm{mL})\end{array}$ & $\begin{array}{c}\text { Plasma } \\
\text { VitC before VitC after } \\
(\mu \mathrm{mol} / \mathrm{L})\end{array}$ & $\begin{array}{c}\text { Plasma } \\
(\mathrm{mmol} / \mathrm{L})\end{array}$ \\
102 & 3.74 & 11 & 31.2 & 50 & 25.5 & 9.07 & 21.37 & 8.87 & 17.5 & 2.4 & 25.6 & 10.05 \\
108 & 3.81 & 8.47 & 40.5 & 212.1 & 8.6 & 0.86 & 12.58 & 5.35 & 13.76 & 1.7 & & \\
129 & 4.54 & 6.93 & 41.5 & 234.5 & 6.4 & 1.96 & 3.93 & 6.06 & 12.53 & 1.4 & \\
94 & 3.41 & 8.49 & 37.5 & 134 & 22.6 & 0.65 & 26.75 & 7.45 & 24.54 & 2.8 & & \\
116 & 4.23 & 6.6 & 43.9 & 191 & 12 & 0.84 & 7.98 & 5.89 & 16.38 & 1.8 & 58.5 & 12.272 \\
\hline
\end{tabular}

HGB: Haemoglobin; RBC: Red Blood Cell; WBC: White Blood Cell; ALB: Albumin; PA: Prealbumin; CRP: C-Reactive Protein; CEA: Carcinoembryonic Antigen; SCC: Squamous Cell Carcinoma Antigen 
quence of the synergy of high-concentration pro-oxidant $\mathrm{VitC}$ in the immediate vicinity of the cell membrane of malignant cells, which are selectively targeted by the mEHT in its membrane rafts. This will also need to be investigated in future research

\section{Conclusion}

This patient's long period of stable disease could have been due to his histologic type (squamous cell carcinoma), which might be more sensitive than other types of NSCLC to the treatments. It is possible that the combination of oncothermia with VitC infusion may increase the plasma VitC concentration over IV VitC alone, which might accelerate the apoptosis of cancer cells. Although very preliminary, the positive results of the present study warrant further exploration of its efficacy, particularly for patients who are not eligible for or who refuse conventional treatments (surgery, chemotherapy, radiotherapy). In addition, studies are needed to determine the best treatment protocol for the combination of mEHT with VitC infusion.

\section{Conflict of Interests}

There is no conflict of interest to declare.

\section{References}

1. Chen W, Zheng R, Baade PD, Zhang S, Zeng H, Bray F, Jemal

A, Yu XQ, He J. Cancer statistics in China, 2015, CA Cancer J Clin 2016;66(2):115-32.

2. Wakelee HA, Bernardo P, Johnson DH, Schiller JH. Changes in the natural history of non-small cell lung cancer (NSCLC)--comparison of outcomes and characteristics in patients with advanced NSCLC entered in Eastern Cooperative Oncology Group trials before and after 1990 Cancer 2006;106(10):2208-17.

3. Jie Luo, Li Shen, Di Zheng. Association between vitamin C intake and lung cancer: a dose-response meta-analysis. Sci Rep 2014;4:6161.

4. Chiang CD, Song E, Yang VC, Chao CC. Ascorbic acid increases drug accumulation and reverses vincristine resistance of human nonsmall cell lung cancer cell. Biochem J 1994;301 (Pt 3):759-64.

5. Wilson MK, Baguley BC, Wall C, Jameston MB, Findlay MP, Review of high-dose intravenous vitamin $\mathrm{C}$ as an anticancer agent. Asia Pac J Clin Oncol 2014;10(1):22-37.

6. Cameron E, Pauling L. Supplemental ascorbate in the supportive treatment of cancer: reevaluation of prolongation of survival times in terminal human cancer. Proc Natl Acad Sci U S A 1978;75(9):4538-42. 7. Cameron E, Campbell A. Innovation vs. quality control: an "unpublishable" clinical trial of supplemental ascorbate in incurable cancer. Med Hypotheses 1991;36(3):185-9.

8. Creagan ET, Moertel CG, O'Fallon JR, Schutt AJ, O'Connell MJ, Rubin J, Frytak S. Failure of high-dose vitamin C (ascorbic acid) therapy to benefit patients with advanced cancer. A controlled trial. N Engl J Med 1979;301(13):687-90

9. Moertel CG, Fleming TR, Creagan ET, Rubin J, O'Connell MJ, Ames MM. High-dose vitamin C versus placebo in the treatment of patients with advanced cancer who have had no prior chemotherapy. A randomised double-blind comparison. N Engl J Med 1985;312(3):137-
41.

10. Chen Q. Vitamin C in Cancer Treatment: Where Pharmacokinetics Speaks. J Drug Metab Toxicol 2012;3(3):e107.

11. Padayatty SJ, Levine M. Reevaluation of ascorbate in cancer treatment: emerging evidence, open minds and serendipity. J Am Coll Nutr. 2000;19(4):423-5.

12. Chen Q, Espey MG, Sun AY, Pooput C, Kirk KL, Krishna MC, Khosh DB, Drisko J, Levine M. Pharmacologic doses of ascorbate act as a prooxidant and decrease growth of aggressive tumor xenografts in mice. Proc Natl Scad Sci USA 2008;105(32):11105-9.

13. Hoffer LJ, Levine M, Assouline S, Melnychuk D, Padayatty SJ, Rosadiuk K, Rousseau C, Robitaille L, Miller WH Jr. Phase I clinical trial of i.v. ascorbic acid in advanced malignancy. Ann Oncol 2008;19(11):1969-74.

14. Padayatty SJ, Sun H, Wang Y, Riordan HD, Hewitt SM, Katz A, Wesley RA, Levine M. Vitamin C pharmacokinetics: Implications for oral and intravenous use. Ann Intern Med 2004;140(7):533-7.

15. Monti DA, Mitchell E, Bazzan AJ, Littman S, Zabrecky G, Yeo CJ, Pillai MV, Newberg AB, Deshmukh S, Levine M. Phase I evaluation of intravenous ascorbic acid in combination with gemcitabine and erlotinib in patients with metastatic pancreatic cancer. PLoS One 2012;7(1):e29794.

16. Chen Q, Espey MG, Krishna MC, Mitchell JB, Corpe CP, Buettner GR, Shacter E, Levine M. Pharmacologic ascorbic acid concentrations selectively kill cancer cells: action as a pro-drug to deliver hydrogen peroxide to tissues. Proc Natl Acad Sci U S A 2005;102(38):13604-9.

17. Chen Q, Espey MG, Sun AY, Lee JH, Krishna MC, Shacter E, Choyke PL, Pooput C, Kirk KL, Buettner GR, Levine M. Ascorbate in pharmacologic concentrations selectively generates ascorbate radical and hydrogen peroxide in extracellular fluid in vivo. Proc Natl Acad Sci U S A 2007;104(21):8749-54.

18. Frel B, Lawson S. Vitamin C and cancer revisited. Proc Natl Acad Sci U S A 2008;105(32):11037-8.

19. Carosio R, Zuccari G, Orienti I, Mangraviti S, Montaldo PG. Sodium ascorbate induces apoptosis in neuroblastoma cell lines by interfering with iron uptake. Mol Cancer 2007;30;6:55.

20. Ma Y, Chapman J, Levine M, Polireddy K, Drisko J, Chen Q. High-dose parenteral ascorbate enhanced chemosensitivity of ovarian cancer and reduced toxicity of chemotherapy. Sci Transl Med 2014;6(222):222ra18

21. Jamison JM, Gilloteaux J, Taper HS, Summers JL. Evaluation of the in vitro and in vivo antitumor activities of vitamin $\mathrm{C}$ and $\mathrm{K}-3$ combinations against human prostate cancer. J Nutr 2001;131(1):158S-160S.

22. Chen P, Yu J, Chalmers B, Drisko J, Yang J, Li B, Chen Q. Pharmacological ascorbate induces cytotoxicity in prostate cancer cells through ATP depletion and the induction of autophagy. Anticancer Drugs 2012;23(4):437-44.

23. Welsh JL, Wagner BA, van't Erve TJ, Zehr PS, Berg DJ, Halfdanarson TR, Yee NS, Bodeker KL, Du J, Roberts LJ 2nd, Drisko J, Levine M, Buettner GR, Cullen JJ. Pharmacological ascorbate with gemcitabine for the control of metastatic and node-positive pancreatic cancer (PACMAN): Results from a phase I clinical trial. Cancer Chemother Pharmacol 2013;71(3):765-75.

24. Mikirova N, Casciari J, Riordan N, Hunninghake R. Clinical experience with intravenous administration of ascorbic acid: achievable lev- 
els in blood for different states of inflammation and disease in cancer patients. J Transl Med 2013;11:191.

25. Lee DY, Park JS, Jung HC, Byun ES, Haam SJ, Lee SS. The outcome of the chemotherapy and oncothermia for far advanced adenocarcinoma of the lung: Case reports of four patients. Adv Lung Cancer 2015;4(1):1-7

26. Lee Y. Oncothermia applications for various malignant diseases. Conf. Pap. Med. 2013;2013:Article ID 245156.

27. Rubovszky G, Nagy T, Szasz A, Lang I. Successful co-administration of electrohyperthermia and bevacizumab in non-small cell cancer: A case presentation. (poster). Oncothermia Journal 2011;3:62.

28. Yeo SG. Definitive radiotherapy with concurrent oncothermia for stage IIIB non-small-cell lung cancer: A case report. Exp Ther Med 2015;10(2):769-72.

29. Jeung TS, Ma SY, Lim S, Sangwook L. Cases that respond to oncothermia monotherapy. Conference of the International Clinical Hyperthermia Society 2012. Budapest, 2013.

30. Yoon SM, Lee JS. Case of abscopal effect with metastatic nonsmall-cell lung cancer. Oncothermia Journal 2012;5:53-7.

31. Dani A, Varkonyi A, Magyar T, Szasz A. Clinical study for advanced non-small-cell lung cancer treated by oncothermia. Oncothermia Journal 2011;3:40-9.

32. Dani A, Varkonyi A, Osvath M, Szasz A. Treatment of advanced non-small cell lung cancer by electro-hyperthermia. ESMO 2004.

33. Szasz A. Current status of oncothermia therapy of lung cancer. Ko- rean J Thorac Cardiovasc Surg 2014;47(2):77-93.

34. Lee DY, Haam SJ, Kim TH, Lim JY, Kim EJ, Kim NY. Oncothermia with chemotherapy in the patients with small cell lung cancer. Conference of the International Clinical Hyperthermia Society 2012. Budapest, 2013.

35. Andocs G, Renner H, Balogh L, Fonyad L, Jakab C, Szasz A. Strong synergy of heat and modulated electro- magnetic field in tumor cell killing, Study of HT29 xenograft tumors in a nude mice model. Strahlenther Onkol 2009;185(2):120-6.

36. Szasz O, Szasz A. Oncothermia - Nano-heating paradigm. J Cancer Sci Ther 2014;6(4):114-21.

37. Szasz O. burden of oncothermia - why is it special? Conference of the International Clinical Hyperthermia Society 2012. Budapest, 2013.

38. Andocs G, Rehman MU, Zhao QL, Papp E, Kondo T, Szasz A. Nanoheating without Artificial Nanoparticles Part II. Experimental support of the nanoheating concept of the modulated electrohyperthermia method, using U937 cell suspension model. Biol Med 2015;7(4):1-9.

39. Hegyi G, Szigeti GP, Szasz A. Hyperthermia versus oncothermia: cellular effects in complementary cancer therapy. Evid Based Complementary Alternat Med 2013;2013:672873.

40. Hoffer LJ, Robitaille L, Zakarian R, Melnychuk D, Kavan P, Agulnik J, Cohen V, Small D, Miller WH Jr. High-dose intravenous vitamin $\mathrm{C}$ combined with cytotoxic chemotherapy in patients with advanced cancer: a phase I-II clinical trial. PLoS One 2015;10(4):e0120228. 